\title{
Reflections on American Religiosity from an Eliasian Point of View*
}

\author{
STePHEN MenNeLL ${ }^{* *}$
}

\begin{abstract}
From a European point of view, one of the most puzzling aspects of the contemporary USA is the large proportion of its citizens who assent to belief in the supernatural. In sociology, that has given rise to a debate about whether secularising Europe or the religious USA represents 'normality' and which is 'exceptional'. In this essay, the work of Norbert Elias is used in an explanatory way to shed light on the peculiarities of America. Although Elias has often been accused of neglecting religion in his theory of civilising processes, it is argued that his closely related sociological theory of knowledge and the sciences is useful in this context.
\end{abstract}

Keywords: religion, religiosity, USA, America, Norbert Elias, civilising processes, fantasy, supernatural

Religion (...) never has in itself a 'civilising'

or affect-subduing effect. On the contrary,

religion is always exactly as 'civilised' as the

society or class which upholds it.

Norbert Elias [2000: 169]

Viewed from Europe, where there has been a marked trend towards secularisation in most countries for well over a century, the enduring religiosity of the USA is perplexing. Religion has been succinctly defined as 'the invocation of the supernatural' [Wilson, 1982: 154]. And even at the highest levels in the USA, rhetoric is deployed about a personal God who actively gives direction through prayer. Presidential prayer meetings are publicised, especially at times of international crisis. The question is whether the rhetoric of religion in politics is a veneer, or whether it does indicate the actual role of religious thinking in policy-making. It may simply be that the boundaries between what Pierre Bourdieu called 'fields of discourse' are drawn differently in the USA. It may even be true that the proportion of political leaders in other Western countries who privately adhere to religious beliefs is no smaller than in the USA. But religious belief is regarded in Europe as largely a private matter - it has to a greater extent been pushed 'behind the scenes' of public life - and rhetorical invocation of the supernatural in political discourse is now uncommon and embarrassing. On the other hand, it has been argued, notably by sociologists of religion like Greeley [1989; 2003] and Davie [2002], that in global perspective it is secularising Europe, not America, that is the exception. But whether or not that is the case, the apparent persistence of religion embodying a strong element of 'magic-mythical' thinking, would appear to be at odds with Norbert Elias's sociological

* This essay is a shortened and revised version of chapter 11 of my book The American Civilizing Pro-cess [Mennell 2007].

** Prof. Stephen Mennell is Professor Emeritus of Sociology at University College Dublin, Belfield, Dublin 4. E-mail: Stephen.Mennell@ucd.ie 
theory of knowledge and the sciences. Why in America does there endure a wider range of variation than in Europe in the social standards about what it is socially respectable to believe about the natural and social world, in what circumstances, and with what possible consequences?

\section{Fantasy and the growth of knowledge}

Elias's magnum opus, The Civilizing Process, has often been criticised for omitting to discuss the civilising influence that religion is very widely assumed to have had. That assumption, according to Goudsblom [2004], is rooted in the dominant intellectual tradition deriving from St Augustine, which singles out religious belief as a powerful force in the strong shift in socially induced individual self-control observed from the Renaissance onwards. In The Protestant Ethic [1930] - one of the most influential founding texts of modern sociology - Max Weber leaned heavily towards the Augustinian view. Elias, on the other hand, can be placed within what Goudsblom calls the Lucretian tradition. The first-century BC writer Lucretius, in De rerum natura [1951], anticipated the modern theory of evolution, and he attributed religious belief to people's ignorance of principles underlying life on earth. Elias recognised that religious organisation may have played a part in exerting civilising pressures; he treats princes of the church as no different from secular princes in the feudal power struggles out of which processes of state formation arose [2000: 187]. This idea has been developed by Mart Bax [1987], who argued that additional impetus was given to the European civilising process by competition between religious and secular authorities. Unlike Weber, however, Elias gave little credence to the independent civilising influence of religious ideas. ${ }^{1}$

What Elias did advance in many essays from the 1950s to the 1980s was a strong theory of the long-term development of knowledge and the sciences. Closely connected with the earlier theory of civilising processes, it is not explicitly a theory of religion, still less of secularisation, but it is concerned with the balance between 'involvement' and 'detachment', and between 'magic-mythical' and relatively more 'reality congruent' thinking. ${ }^{2}$

Elias spoke of a balance between 'detachment' and 'involvement', rather than using more conventional dichotomies like 'rational' and 'irrational', 'objective' and 'subjective'. Most adult behaviour lies on a scale between total involvement and total detachment.

One cannot say of a [person's] outlook in any absolute sense that it is detached or involved (or, if one prefers, 'rational' or 'irrational', 'objective' or 'subjective'). Only small babies, and among adults perhaps only insane people, become involved in whatever they experience with complete abandon to their feelings here and now; and again only insane people can remain totally unmoved by what goes on around them [2007a: 68].

1 A notable and fascinating example of the Augustinian approach in the study of American religion is Baltzell's Puritan Boston and Quaker Philadelphia [1979], in which he attributes to 'two Protestant Ethics' a decisive difference in 'class authority and leadership' and ultimately economic growth in the two cities. For all the interest of the cultural differences between two elites, however, the causal inference is weak.

2 For Elias's sociology of knowledge and the sciences, see Involvement and Detachment [2007a] and Essays I: On the Sociology of Knowledge and the Sciences [2009]. For an overall account of Elias's writings in this area, see Mennell [1998: 158-99]. 
Besides, not only do 'irrational' and 'subjective' often have pejorative overtones, they also tend to imply 'psychological' characteristics of a particular individual, whereas the criteria by which Elias judges the balance between involvement and detachment cover both the 'psychological' and the 'social'. The balance of involvement and detachment varies between different human groups, from situation to situation within them, and from individual to individual within a situation. Nevertheless, the way in which individual members of a group experience whatever affects their senses, the meaning it has for them, depends on the standard forms of dealing with, and of thinking about, these phenomena gradually evolved in their society [2007a: 70].

For example, in modern industrial societies people employ, as part of the knowledge they have inherited from the past and now take for granted, a very precise conceptual distinction between living and non-living things [2007a: 120]. The distinction is highly 'reality-congruent' - it consistently 'works' with a high degree of certainty. Individual reactions when experiencing the forces of nature - a thunderstorm, a forest fire, even an illness - may still vary from individual to individual and situation to situation, but in scientific societies the concepts which all individuals now use in thinking, speaking and acting represent a relatively high degree of detachment. That is true of concepts like 'hurricane', 'lightning', 'tree', 'disease', as well as 'electricity', 'cause', 'time', 'organism'. Today there is very little scope for hurricane, lightning and fire - and only a little more for illness - to be interpreted in terms of the intentions of supernatural living beings and their meaning for the particular humans affected. In other words, the range of individual variations in interpreting natural events is limited by the public standards of detachment embodied in modes of thinking and speaking about nature [2007a: 120]. This is markedly less true of modes of thinking and speaking about things that happen in what we call 'society' as opposed to 'nature'.

Members of industrial societies have great difficulties in understanding that members of societies at earlier stages of development were often unable to distinguish what they themselves distinguish easily and as a matter of course. Their assumption of a clear distinction between living and non-living things, for instance, can be so easily confirmed by testing against reality that it is hard to imagine that anyone can ever have failed to make it. Yet in fact this distinction took a very long time to develop to its present form. At some stage in the past, human beings could not yet know that a hurricane or a raging sea which put their lives at risk was itself not alive. The very phrase 'raging sea', though now only a metaphor, helps the effort of imagination needed to put oneself in the place of people who were not aware that the storms which destroyed human life did so unintentionally, and were blind physical processes.

By the seventeenth century when the colonisation of North America began, the animate/inanimate distinction at least was fairly firm in the minds of English people. But they retained many other beliefs that from a modern standpoint seem absurd. Eggleston, in his pioneering study [1901] of the 'mental furniture' that early settlers took on board ship with them, mentions: the unclear distinction between astronomy and astrology, with horoscopes cast even by famous astronomers; comets being seen as portents; the belief in the spontaneous generation of worms, birds and fish from dead bodies, trees or the sea; the belief in an invisible world, including most famously the activities of witches and witchcraft. Noting the Salem witch trials of 1692, much studied by later historians, Eggleston observes that 
The phenomena known in later times as hysteria, and as mesmerism and hypnotism, were not yet recognised to be due to natural causes. The infinitely delicate shadings by which mental sanity passes without line of demarcation into madness could then not be imagined [1901: 26-7].

Similarly, people have not always been quite sure that a person could not transform him or herself into an animal or a tree. To be certain that that was not possible was all the more difficult because these things did happen in dreams: people could easily see themselves or other people changing, or being changed, into trees or birds or animals. Such themes now persist for us mainly in the magic and myths of folklore and children's tales: if they happen in dreams, we know they are only dreams. But how could human beings know, from the very beginning, that many things which happen in dreams could not happen in reality? Elias points out that for small children everywhere, the difference between fantasy and reality is blurred. They learn the distinction between fantasy and reality, like other items of knowledge, in accordance with the standard reached in their society [2007a: 121$]$.

How distinctly the line is drawn between dreams and reality depends on public standards, which in industrial societies demand that people draw it very clearly and act accordingly. If they act out their dreams in a way not in line with the standard their sanity may be questioned. Children have to learn this. But magical-mythical thinking, highly loaded with fantasy, is 'the primary mode of human experience' because it is part of the elementary makeup of human beings that 'their emotions, their affects and drives, are primarily attuned to other persons on whom they can fasten, rather than to lifeless things' [2007a: 128]. This mode of experience does not simply cease to exist in industrialscientific societies. As people grow up, it becomes a more or less submerged layer of the personality structure. Freud discovered it there and called it the 'unconscious'. The magical-mythical mode of experience remains alive in adults in modern societies, and is allowed relatively greater expression in some areas - cultural life, religion and politics for example - than in the domain of the natural sciences themselves. It is also seen in the popular appeal of science fiction, astrology and parapsychology.

In the natural sciences, the question characteristic of people's involvement, 'What does it mean for me or us?', has become more subordinated to questions like 'What is it?' or 'How are these events connected with each other?' The level of detachment represented by the latter questions has been buttressed and institutionalised as part of a scientific tradition transmitted by means of a highly specialised training, maintained by various forms of social control and socially induced emotional restraints. It has become embodied in the conceptual tools, the basic assumptions, the methods of speaking and thinking which scientists use. Scientific concepts and theories in the natural sciences embody the idea of a relatively autonomous, impersonal order in events. Scientific communities are relatively autonomous in their social organisation, and exercise strong control over what it is acceptable for scientists to believe about the natural world.

As the stock of knowledge has grown, concepts of the more detached, scientific type have gradually spread to people at large. In industrial societies, most people use concepts and explanations of natural events based on the idea of a course of events independent of any specific group of human observers, without being aware of the long struggle that was necessary to develop these modes of thinking. Certainly, other more 
involved layers of experience persist alongside the more detached - as in the case of illness, where a scientific understanding of organisms may not quite drive out the question 'What have I done to deserve this?' In understanding social processes, the level of habitual detachment for most people remains much less than in the case of 'natural' processes. The institutionalised curbs on emotions and fantasy in the pursuit of understanding vary along a broad continuum. Many churches, especially in the past, sought to impose strict limits on acceptable belief through tight social discipline and elaborate doctrine. But, while the long-term trend may be towards higher social standards of detachment in some fields - most obviously the natural sciences and to the lesser extent the social sciences - in other fields it is arguable that spurts in the opposite direction are quite common.

\section{American religion in long-term perspective}

Organised religion and large-scale agriculture make their appearance in human history at the same time. The capacity for symbolic thought, permitting humans to speculate about the causes of natural and social events, is much older - it dates back at least to the emergence of Homo sapiens sapiens and probably much further. But specialised religious institutions, with organisational structures, specialised personnel - priests - and articulated bodies of doctrine, appeared only in connection with agriculture. 'Religiousagrarian regimes' tended to be supplanted by 'military-agrarian regimes', because the vulnerability of fields, crops and barns to marauding pillagers made defence (and exploitation) of farmers by specialist warriors more or less indispensable [Goudsblom 1996a; 1996b]. Yet priestly elites tended to endure, in alliance with the warrior rulers. The role and power of priests can be understood in relation to the kinds of danger that agriculturalists face. Natural dangers include droughts, floods, crop failures, infestations by weeds, insects and other parasites, soil exhaustion and erosion. These cannot always be prevented even today, let alone with the technology that was available in the past. But they can be exacerbated by human failings: negligence, ignorance, greed, lack of care, lack of discipline, lack of foresight. Priests seem to have played a part in deterring such failings. For millennia [Elias 2007b: 42-5] they acted as timekeepers, using astronomic observations to determine the seasons for sowing and reaping. In many societies, religious ritual came to be employed as a means of promoting good practice and preventing bad through social control and discipline: people were made to fear the consequences, social and supernatural, of sowing crops at the wrong time, of bingeing on the new harvest and being hungrier later, of eating the seed corn.

\section{Danger and superstition}

Elias makes an essential connection between practical dangers, the corresponding levels of fear, and the balance between emotional involvement and detachment. The early European settlements in North America were no doubt very different from the early agrarian societies of millennia before, but they still faced many of the same dangers. Seventeenthcentury people in both Europe and North America lived with a pervasive sense of uncertainty, of having to cope with a capriciously dangerous world over which they could exert little control [Thomas 1973: 3-24; Muchembled 1985: 31-33, 119 ff.]. Drawing on diaries from the period, Carol Stearns shows that this extended even to the protection of children: 
in the specific case of children, indeed, one is struck by how unprotected they were, with near-fatal accidents a commonplace in the diaries. The recording of these in part simply restated the view that one has no control over the world, but it indicated that the parents involved took little care to structure the environments of children in order to systematically protect them from danger. (...) they simply did not see the world as a controllable place and think in terms of controlling it [Stearns 1988: 56-7].

Stearns characterised the typical emotional response to misfortune in the early modern period as one of 'sadness' rather than anger, explaining it precisely by the lack of a sense of control. This enhanced the appeal to religious belief - explanations were routinely sought in 'the will of God' - but also, as Keith Thomas demonstrated, the appeal of superstition of all kinds and specifically the belief in witchcraft. Gradually, in the first half of the eighteenth century, the lack of a sense of control began to be replaced, especially among the middle and upper classes, by a sense that a greater degree of control was possible over at least some of the commoner dangers. It is tempting to relate this to intellectual developments, including the divorce between magic and science that gained momentum in the seventeenth century, and led into the Enlightenment of the eighteenth [Thomas 1973: 767-800]. The influence of ideas must not be dismissed entirely, and they do typically percolate very slowly downwards from intellectual elites to the wider society. But it could equally well be argued that Enlightenment ideas were a response to the world's becoming for some people somewhat less dangerous and more manipulable. (For instance, the threat of famine gradually diminished at this time because of improvements in transport and commerce.) Certainly the belief in witchcraft declined. Yet for many people, including farmers in the remoter parts of the expanding USA, life remained highly dangerous, capriciously so, and there are many accounts of the prevalence of superstition on the frontier in the nineteenth century.

At first glance, the prevalence of superstition and magical beliefs may seem to be at odds with the traditional image of American settlers, especially with the rigid regulation of conduct and beliefs in early New England. There remained to a great extent a volatility and impulsiveness still reminiscent of the Middle Ages. Learned and responsible men could still be carried away, as was Samuel Sewall, who came to look back with remorse on his role as judge in the Salem witch trials; he made a public confession of error and guilt in Old South Church in Boston just five years after the events. The rigid morality and doctrine of some of the early established churches - particularly in Massachusetts, which perhaps looms too large in popular perception - is only one side of the equation.

\section{Established churches}

Initially, established churches were a feature of several of the colonies, but only in Massachusetts was a serious attempt made to impose religious uniformity, to monopolise the means of orientation, in a theocratic state. From the beginning, that provoked conflict, and the Massachusetts theocracy effectively came to an end with the granting of a new royal charter in 1691, although religious elites remained powerful in New England for much longer. Eventually, the Bill of Rights was constitutionally to forbid the imposition of an established religion by the federal government: the First Amendment stipulated that 'Congress shall make no law respecting an establishment of religion, or prohibiting 
the free exercise thereof'. As a result, in retrospect an established church appears distinctly un-American, although the last vestiges of establishment at state level persisted in Connecticut until 1818 and Massachusetts until 1833.

It is of some long-term significance that not even in Massachusetts or Connecticut did clerical elites in the end secure a permanent place in the central monopoly of the power structure of American society. A comparison with Latin America is instructive. In the Spanish colonies, there was a classic symbiosis of priestly and warrior power. Darcy Ribeiro observes that the Catholic Church's association with the temporal power gave it everything the state could provide - an architectural heritage in its churches altogether more spectacular than those of North America is one sign of the use made of the state's taxing power - but in return the state acquired the Church's 'co-operation in perpetuating colonial domination and maintaining the oligarchic order and in aristocratising its upper hierarchy' [1971: 351]. Ribeiro, like Elias (but in more detail), paid more attention to the Church's and the clergy's position in the power structure than to the 'psychological' effects of particular religious beliefs on which sociologists since Max Weber have tended to dwell. ${ }^{3}$ In Latin America, the Church's power gave rise to militant anti-clerical and secularist movements, whereas 'the clergy of Protestant America, excluded from the political power structure, could always safeguard itself better and exert a control that, though more informal, was more efficacious' [1971: 351]. This point connects well with Elias's argument that moderate, but sustained and consistent, social pressures are more effective in bringing about the internalisation of changing social standards as taken-for-granted habitus or 'second nature'. Ribeiro contended that 'religion in Protestant America became actually more orthodox than Latin American Catholicism, generalising as a more popular religiosity, less impregnated with syncretisms, but also more intolerant' [1971: 351-2, italics S. M.]. The last phrase is rather startling, unless one is thinking of the extreme right-wing Christians who have risen to prominence in the USA mainly since Ribeiro was writing in the 1960s. But Ribeiro's comparison does offer some insight into the persistence of religiosity in the USA, and why for a much larger proportion of Americans than Western Europeans it remains taken-for-granted 'second nature' to assent to religious belief and even belong to a religious organisation.

\section{Civil religion}

One way in which taken-for-grantedness has taken root has been the institutionalisation in the USA of what Robert Bellah [1967], following Rousseau, called a 'Civil Religion'. In spite of the constitutional prohibition of any religious establishment, the phrase 'In God we Trust' appears on American coins, children daily swear allegiance to 'one nation, under God', and reference has been made to 'God' in the inaugural addresses of every President. ${ }^{4}$ Yet this God is not specifically Christian or Jewish, let alone Protestant

3 Ribeiro does not dismiss ideological differences out of hand. He notes the influence of the encouragement to read the Bible in the case of the Protestants, in contrast with 'the conservatism, expressed in the insistence on attitudes of resignation to ignorance, backwardness and poverty, in the traditional Catholic ideology' [1971: 350]. But he nevertheless attributes the famous 'Protestant work ethic' more to differences in the prevalent mode of labour recruitment: the predominance of the wage-earner class and a resulting view of dignity of labour in the one case, and serfdom and slavery in the other.

4 Max Weber commented [1946: 303n] that 'The opening by prayer of not only every session of the US Supreme Court but also of every Party Convention has been an annoying ceremonial for quite some time.' 
or Catholic, and many of these invocations are phrased sufficiently abstractly, especially nowadays, not to exclude Islam. This generalised religion appears, from George Washington onwards, to be connected with the conviction that without belief in God, morality public or private cannot be securely based - a proposition to which a large proportion of Americans assents today. ${ }^{5}$ It is something separate from, but drawing upon, conventional religion. As Bellah pointed out, the Revolution has long been implicitly depicted as an American Exodus, while the Civil War provided an American New Testament, with Lincoln as the murdered God - an idea, as Frazer showed in The Golden Bough [1958, (1890)], common in the mythology of the ancient world and central to Christian belief. This civil religion can be dismissively stamped 'American Shinto' [Bellah 1967: 12], but as a nationally sponsored syncretism it appears to function in a way that legitimates more specific religious beliefs and their respective organisations, subtly casting a patriotic cloak over them. ${ }^{6}$

\section{Great awakenings}

In ordinary religious observance among Americans, there would seem to be several more or less long-term trends that are not altogether easy to explain. One is a cyclical pattern of upsurges of religious fervour known as 'Great Awakenings'. The First Great Awakening swept the colonies in the 1730s and 1740s [Ahlstrom 1972: 280-330]; Jonathan Edwards, minister at Northampton, Massachusetts, is generally seen as its intellectual leader, but the great English Methodist preacher George Whitefield visited North America and preached from New England to the South. The notion of being 'born again' in Christ, still prominent in American religion today, was prominent in the preaching of the First Great Awakening. The opponents of the revival, particularly liberal pastors of the established church in Massachusetts, criticised it for encouraging emotional excess and religious delusions.

Two generations later, a further revival movement, known as the Second Great Awakening [Ahlstrom 1972: 415-35], began once again in New England, but swept westwards - Kentucky was an especially important centre - in the early decades of the nineteenth century. It is associated with the 'camp meetings' characteristic of religious enthusiasm as the frontier moved west, and was also linked with the growth of anti-slavery sentiment. There is nothing very unusual about such upsurges, which occurred in many pre-industrial agrarian societies. ${ }^{?}$

5 In a national survey conducted by the Pew Research Centre in March 2002, 47 per cent of respondents assented to the view that a belief in God was necessary in order to be a moral person, but slightly more (50 per cent) deemed it unnecessary. The vagaries of opinion surveys are exposed, however, by 84 per cent of respondents also expressing the view that a person can be a good American if he or she does not have religious faith, while just 13 per cent disagreed. One commentator calculated that this implied that nearly half of Americans believed that it was possible to be a good citizen without being moral.

6 And it has served to spread the odour of sanctity around American foreign policy. Bellah's famous essay was written at the time of the Vietnam War, and he noted that the civil religion 'has often been used and is being used today as a cloak for petty interests and ugly passions' [1967: 16, 18-19]. The same remark could apply to the American invasion of Iraq. Catherine Albanese [1992] contended that the civil religion had gone into decline from the 1960s, but it has arguably reasserted itself in the early years of the twenty-first century.

7 That is not to imply that such upsurges represent totally spontaneous movements of the spirit; both the First and Second Great Awakenings were highly organised and planned campaigns [Finke and Stark 2005: $55 \mathrm{ff}$.]. 
The next widespread religious upsurge was very different in character. The Social Gospel movement [Ahlstrom 1972: 785-804], at its height from roughly the 1890s to the 1920s, unlike the First and Second Great Awakenings, was quintessentially a product of the new urban-industrial capitalist society rather than of the early republic of small farmers. It had affinities with the European Christian socialist movements in its criticism of the inequality and poverty produced by the unbridled market forces of American laissezfaire. It was the religious expression of the Progressive era, and had close intellectual links with social scientists such as the economist Richard T. Ely and the sociologist Albion Small who stood in opposition to the dominant school led by William Graham Sumner which, under the influence of Herbert Spencer, opposed all attempts to interfere with the survival of the fittest in the market place.

The most recent upsurge in this cyclical pattern of religious enthusiasm began in the 1960s and still continues at the beginning of the twenty-first century. This is the antithesis of the Social Gospel; dominated by evangelicals and Pentecostalists, its central religious concerns are with individual salvation, personal revelation and being 'born again', and thus it has much more in common with the First and Second Great Awakenings. Its individualism has allied it politically with a right-wing defence of laissezfaire and hostility to government - and to aspects of modern science. ${ }^{8}$ Its rise has been accompanied by the decline of old-style Protestantism. A columnist in the New York Times captured the trend in a family recollection:

\begin{abstract}
My grandfather was fairly typical of his generation: A devout and active Presbyterian elder, he nonetheless believed firmly in evolution and regarded the Virgin Birth as a pious legend. Those kinds of mainline Christian are vanishing, replaced by evangelicals. Since 1960s, the number of Pentecostalists has increased fourfold, while the number of Epicopalians has dropped almost in half [Kristof 2003].
\end{abstract}

But that is not as new in American history as Kristof implies.

\title{
The replenishment of religious involvement
}

Popular revival movements, argued Wilson [1982: 152], were unwitting vehicles of increased secularisation. From early Methodism to modern Pentecostalism, they drew people to church in larger numbers, stimulating but also disciplining religiosity, eradicating random superstitions, rationalising understanding, undermining priestly authority and minimising mystery. 'Eventually, they provide a new education of the emotions.' Wilson's view is consistent with one aspect of the rich historical data on American religious observance presented by Finke and Stark [2005]. They show that the proportion of Americans who take part in organised religion has substantially increased. On the other hand, they show that this was accomplished by 'aggressive churches committed to vivid other-worldliness' [2005: 1] and high levels of emotional involvement. And, on a larger scale than in Europe, these revivalist movements have continued to the present day. That appears to contradict theories of secularisation as well as my interpretation of Elias's theory about involvement and detachment.

$8 \quad$ Chris Hedges [2007], a prominent American journalist with academic qualifications in theology, has made a scholarly - not sensationalist - case for the Christian Right being an American form of fascism. 
Finke and Stark calculate that in 1776 only about 20 per cent of Americans took an active part in church affairs, whereas as the end of the twentieth century as many as 60 per cent did so. They do not claim that at Independence the other 80 per cent of Americans were necessarily irreligious, but their faith, if they had any, 'lacked public expression and organised influence' [2005: 26]. While the fervour of the First Great Awakening had subsided by then, Finke and Stark do not depict 1776 as a particularly low ebb in church participation. But even in New England, only about one person in five then had a religious affiliation. At Independence, Quakers amounted to only five per cent of the population of Pennsylvania, Catholics only three per cent in Maryland, and detailed calculations yield the overall figure of about 20 per cent religiously affiliated in all 13 colonies [2005: 25]. So today's figure of almost two-thirds of Americans taking part in organised religion is a very striking fact.

More striking still is a general tendency for the emotional temperature of religion to increase over time. Or rather, there is a long history of denominations 'cooling down', of becoming rationalised or intellectualised, of abandoning traditional belief in the literal truth of scripture, and of making fewer emotional demands on their adherents. But, as they did so, they lost 'market share': they ceased to prosper, and newer, more emotionally demanding, denominations grew in their place. The prototypical case was the decline of Congregationalism in Massachusetts. Partly in adverse reaction to the emotionalism of the First Great Awakening, many of the upper classes drifted away in the late eighteenth century towards Unitarianism. Similarly, a century later, many of the Quaker elite of Pennsylvania gravitated towards Episcopalianism: 'Although the "Protestant ethic" still spurred on the parvenu, Proper Philadelphia increasingly preferred the richness of the Anglican ritual' [Baltzell 1958: 13]. But trends among the elite did not make either the Unitarian or the Episcopal Church a market leader. Finke and Stark present quite precise calculations of the rise and fall of the principal denominations' shares of total adherents between 1776 and 1850, and in Figure 1 I have made very roughly comparable calculations for 2001.

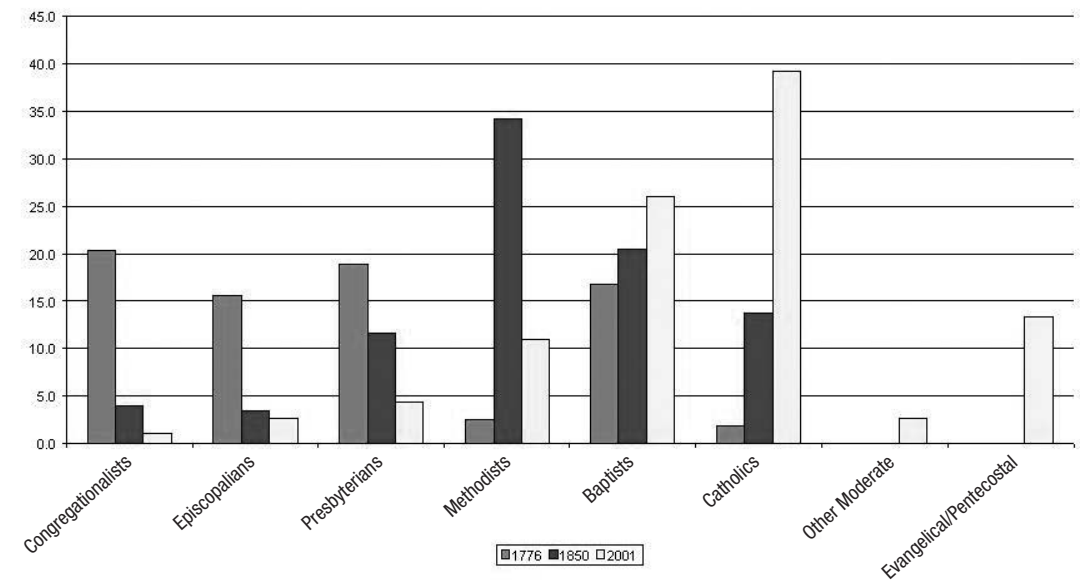

Figure 1: Adherents by Christian Denomination, 1776, 1850, and 2001 (as per cent of total adherents)

Source: Finke and Stark [2005: 56] for 1776 and for 1850 [Kosmin et al. 2002]. 
As can be seen, among the Protestants, the Methodists gained massively in the first half of the nineteenth century; but towards its end, they in turn lost ground rapidly and it was the Baptists' turn to gain it. The Baptists have remained strong, perhaps because they are a diverse church, their congregations including both the relatively staid and the relatively emotionally highly charged (as well as the white and the black, and politically both left-wing and right-wing tendencies). During the twentieth century there had also grown up a substantial bloc of small evangelical and Pentecostalist churches, accounting for perhaps one in seven of people declaring a Christian denominational affiliation. Besides the various Christian denominations, there are of course substantial non-Christian minorities. The largest of these are the Jews, among whom there are also various theological tendencies, followed by growing numbers of Muslims, Buddhists and Hindus.

Finke and Stark contend that the history of American religion has nearly always been written as an account of intellectual progress, of how religious ideas have undergone 'refinement', judged by the secular standards of parsimony, clarity, logical unity and graceful exposition. According to such accounts, 'religious ideas always become more refined (i.e. better) when they are shorn of mystery, miracle, and mysticism - when an active supernatural realm is replaced by abstractions concerning virtue' [2005: 7]. That is to write the history of religion like the history of science. Finke and Stark complain that 'one never encounters standards of theological progress or refinement based on how effectively a doctrine could stir the faithful or satisfy the heart'. Their major thesis is that 'religious organisations can thrive only to the extent that they can comfort souls and motivate sacrifice. (...) theological refinement is the kind of progress that results in organisational bankruptcy' [2005: 8]. ${ }^{9}$

In fact, Finke and Stark's historical evidence seems to show that a sort of 'civilising of religion' - including the curbing of the affects, and increasing constraints on the expression of fantasy - has been happening constantly, but the denominations in which it has been happening have declined in membership relative to others. The process has been equally constantly submerged by the rise of denominations that allowed their adherents to give vent more freely to the emotions and to emotionally satisfying fantasy.

\section{Some explanations}

What explanations can be offered for this continual replenishment of belief in 'an active supernatural realm' at the expense of 'abstractions concerning virtue'?

\section{A 'utilitarian' explanation}

First, is it possible that expressions of spiritual fervour are only a superficial sign of other more basic social benefits that are met by membership of a religious organisation? Marvin Harris considered it more plausible that the 'deepest and most characteristic impulse of

9 While Finke and Stark are no doubt right in detecting a judgement about what is 'better' in traditional accounts of religious progress, they are making a value-judgement of their own about what they consider 'better': they clearly imply that it is a good thing to 'stir the faithful or satisfy the heart'. In contrast, it should be noted that that Elias's theory of knowledge and the sciences is not a theory of 'progress', in the sense of things becoming 'better' in any moral sense, but rather about an unplanned direction of development that may have both 'good' and 'bad' effects. 
the [current] Great Awakening is not the search for ultimate meaning but the search for solutions to America's unsolved economic and social problems. The human quest for ultimate meaning is a formidable force in history, but it rarely if ever exists apart from, above, beyond, or in opposition to the quest for solutions to practical problems. (...) At bottom, [this] Great Awakening is primarily a desperate response to the unsolved problems of malfunctioning consumerism, inflation, the upending of sex roles, break-up of the breadwinner family, alienation from work, oppressive government and corporate bureaucracies, feeling of isolation and loneliness, fear of crime, the bewilderment about the root causes of so many changes happening at once' [1987: 145, 165]. ${ }^{10}$

Lest that still leave any room for a 'spiritual' interpretation, Harris spelled out that he saw the dominant motive force as utilitarian: executives prescribing encounter groups and sensitivity training 'to improve relationships among employees and to step up sales' [1987: 146]. And, in his eyes, the born-again movement incorporates elements of a personal 'gospel of wealth', in which 'material success and physical well-being are signs of God's grace to the individual true believer' [1987: 157]. That is not so very different from the historic mainstream of American Protestantism, except that Harris paid particular attention to the large fortunes accumulated as a sign of grace by leading tele-evangelists.

One problem with Harris's materialist interpretation is that the unsolved practical problems to which he refers are not unique - except perhaps in degree in certain localities - to the USA, so it does not easily explain why trends there are different from those in Europe.

The same objection applies to the more popular and weaker version of the thesis, that the role of religion in the USA is less a matter of belief and more a matter of sociability. The argument is that for a population that is always on the move [see Jasper 2000] and lacking rooted forms of social institution, religious organisations provide a socially sorted, open, available form of belonging, a kind of fraternity that assuages fears and anxieties. They provide networks, as well as moral reinforcement. Whatever people believe, and for whatever reason they believe it, there are rewards that accrue from congregating with believers. ${ }^{11}$ Certainly, as Robert Putnam notes, 'Faith communities in which people worship together are arguably the single most important repository of social capital in America' [2000: 66]. They support a wide range of social activities beyond mere worship; in some areas of the country, there are few other forms of social capital. And in one historic instance, there is no doubt that religious organisations did help to solve one category of practical problems of everyday life - those arising from immigration, the scale of which, until very recent decades, distinguished the USA from most Western European countries.

As an extension to this utilitarian interpretation of American religiosity, it may be suggested that the rewards that accrue to believers include some that are typical of established-outsider relationships. ${ }^{12}$ Loud declarations of 'faith' are often accounts based on a 'minority of the best' - they are also proclamations of moral and social superiority.

10 Harris's thesis has something in common with Wilson's view that 'what goes on in the major churches of Britain is very much more "religious" than what occurs in American churches; in America secularising processes appear to have occurred within the church' [1982: 152].

11 I owe this pithy formulation to David Garland (personal communication).

12 For Elias's theory of established-outsider relationships, see [Elias and Scotson 2008 (1965)]. 
In particular, more powerful groups often use a conspicuous level of self-constraint as a mark of their social position. This is evident from the earliest years of settlement in New England. In other times and places in the course of American history, the discourse of some denominations has been linked to nativism and racism. On the other hand, other sects and denominations have served as vehicles for the emancipation of less powerful groups, helping them to eliminate a 'minority of the worst' from their we-feelings. Equally - as we shall note in a moment - religious groupings also frequently permit the relaxation of emotional self-constraints. Religious belief is protean in its social functions.

\section{Immigration}

Finke and Stark's data do not relate to a generation-to-generation process within a closed society of descendants of the people of colonial America. A very large part of America's population growth came from immigration, many of them from deeply religious peasant backgrounds. There is also some evidence that immigrants from fairly secular backgrounds - secularising European Jews for instance - actually became more religious in America. The dangers and insecurities they faced in an alarming and unfamiliar society, together with the support that churches and synagogues provided in coping with them, would go a long way to explaining this. Immigration has obviously been a large factor in accounting for the size of the Catholic Church today - it is by far the largest single Christian denomination, even though all the numerous Protestant groups together still form an overall majority. The expansion of Catholicism in the USA was driven by the arrival first of Irish, then Italian, Polish and other European Catholic immigrants, and more recently Latin Americans. Nevertheless, as Finke and Stark emphasise, the Catholic Church could not take their adherence for granted, but had to compete with other churches, which it did among other things by developing a vast social infrastructure of schools and colleges.

Some doubt remains, however, about whether an explanation of high rates of membership of religious organisations by the contribution it makes to solving practical problems of everyday life can equally explain the persistent drift towards the highfervour forms of religion.

\section{Fundamentalism}

Especially notable is the strength in the USA of 'fundamentalism', a force that is particularly associated with the various evangelical and Pentecostalist churches that grew up in the course of the twentieth century, but is found in other churches (and other religions) too. The term 'fundamentalism' requires some explanation, particularly because at the beginning of the twenty-first century it is often preceded by the adjective 'Islamic'. Yet, as Karen Armstrong [2000: 141] has said, Islam was the last of the major world religions to develop a fundamentalist strain, from the 1960s and 1970s onwards. Before that came fundamentalist Judaism, fundamentalist Hinduism, fundamentalist Buddhism, fundamentalist Sikhism, 'and even fundamentalist Confucianism' [2000: 140]. But first of all there was the fundamentalist Christianity that emerged in the USA early in the twentieth century.

Peter Berger [2006] has pointed out that contemporary America - but not just America - is in the grip of two apparently contradictory cultural currents, fundamentalism and relativism. Only apparently, because he sees them as closely interlinked, both 
being products of the same processes of 'modernisation', and both precluding rational discussion. Relativism, in its various forms, is a reaction to social and cultural pluralisation, while fundamentalisms in all faiths embody a rejection of modern society.

\begin{abstract}
They reveal a deep disenchantment with the modern experiment [sic], which has not fulfilled all that it promised. They also express real fear. Every single fundamentalist movement that I have studied is convinced that the secular establishment is determined to wipe religion out. (...) Fundamentalists look back to a 'golden age' before the irruption of modernity for inspiration, but (...) all are intrinsically modern movements and could have appeared at no time other than our own. (...) Fundamentalists will often express their discontent with a modern development by overstressing those elements that militate against it. They are all - even in the United States - highly critical of democracy and secularism. Because the emancipation of women has been one of the hallmarks of modern culture, fundamentalists tend to emphasise the conventional, agrarian gender roles, putting women back into veils and into the home. The fundamentalist community can thus be seen as the shadow-side of modernity (...) [Armstrong, 2000: 141].
\end{abstract}

Fundamentalisms do not arise in immediate response to the onset of industrialisation, urbanisation, and secularisation, but only when these processes are quite far advanced. Armstrong contends that religious people typically try at first to reform their traditions and blend them with modern culture, but when that fails they resort to more extreme beliefs and methods. For that reason, 'with hindsight, we can see that it was only to be expected that fundamentalism should first make itself known in the United States, the showcase of modernity, and only appear in other parts of the world at a later date' [2000: 140-1]. The rejection of modernity is made especially visible in the retention of late nineteenth-century costume by the Amish, notably in Pennsylvania, and some sects within the ultra-orthodox Jewish community, notably in New York. The celebrated Scopes trial in Tennessee in 1925 marked a stage in the rise of American Christian fundamentalism. That year, the state legislature had passed a law forbidding the teaching of any doctrine contradicting a literal reading of the biblical account of the Creation. A young schoolteacher was prosecuted for teaching the theory of evolution, and those responsible were so ridiculed in the press - as hillbillies and worse - that 'their theology became more reactionary and excessively literal, and they turned from the left to the extreme right of the political spectrum' [Armstrong, 2000: 142]. Over the coming decades fundamentalist sentiments were reinforced by, among other things, the liberalisation of sexuality from the 1960s onwards. By the end of the century, the political strength of fundamentalists was such that not even the scientifically-minded Vice-President Al Gore dared assent to the theory of evolution. ${ }^{13}$ (The Tennessee state law was repealed in 1967, but campaigns to enact similar legislation were launched in various states around the turn of the millennium. ${ }^{14}$ )

\title{
The 'supply side'
}

Yet fundamentalism, it might be argued, is more a part of the explanandum than the explanans for American religious trends: why has such an early rejection of modernity

13 Washington Post, 27 August 1999.

14 Susan Jacoby [2005] provides a very good brief historical account of evolutionism versus creationism controversies since the Scopes trial of 1925. 
persisted and been renewed over so long a period? That question draws attention to the 'supply-side' theory of religious change advanced by Rodney Stark and his associates. Their argument is that too much attention has been paid to the 'demand side', to the preferences of religious consumers, with religious change being attributed to 'cultural realignments', 'crises of faith' or (as in the case of Armstrong's account of fundamentalism), 'flights from modernity' [Finke - Iannaccone 1993]. Stark and his colleagues, in an argument directly derived from supply-side economic theory, set out to show that market forces govern the incentives and opportunities presented to religious producers. More specifically, they contend that, throughout American history, 'deregulation' in the religious marketplace - whether it be the disestablishment of state churches or the opening of the airwaves to evangelical preachers - has led to innovation and increased supply of religious products.

The 'supply side' or 'rational choice' theory of religion poses many problems. It seems to rest upon a socio-biological assumption that all human beings have a constant, unchanging emotional 'need' for supernatural beliefs, that a market always exists in which 'producers' of more magical religious beliefs can sell their wares as older firms' more 'refined' products lose appeal. 'Secularisation', write Finke and Stark [2005: 46], 'is a self-limiting process that leads not to irreligion, but to revival'. The founder of sociobiology, Edward O. Wilson, has in fact written that 'Acceptance of the supernatural conveyed a great advantage throughout prehistory, when the brain was evolving' [1998: 262; see also Burkert 1996]. ${ }^{15}$ Be that as it may, is it so essential today? All suppositions about an unchanging 'human nature' need to be treated with caution. Elias went so far as to speak paradoxically of humankind's 'natural changefulness as a social constant' [1978: 104-10]. At a very general level, it is indeed possible to say that all human beings have a need for 'orientation' [De Swaan 2001: 66-82]. In contrast with other animals, even our nearest biological relatives the chimpanzees, very little of human behaviour is innately programmed. We humans have to learn a vast amount in order to live our lives together with others, and what has to be learned has varied widely between epochs and cultures. But to say that we have a basic need for orientation is very far from saying that we have a continuing need for orientation specifically in terms of an 'active supernatural realm'. There is some evidence that even in the USA a growing minority of people do not feel any such specific need. Between the two large-scale surveys of self-described religious identification in 1990 and 2001, the greatest increase in absolute as well as in percentage terms was among adults who did not subscribe to any. Their number had more than doubled from 14.3 million in 1990 to 29.4 million in 2001, representing a jump from eight per cent of the total US population in 1990 to over fourteen percent in 2001 [Kosmin et al. 2002]. ${ }^{16}$

\section{Quest for excitement in religion}

While there may be no universal need for specific belief in the supernatural, a good case can be made for the 'hotter' forms of religious participation meeting a need that has

15 See Hunt [1999] for a critical discussion of these socio-biological writers.

16 Over the same period there was also a substantial increase in the number of adults who refused to reply to the question about their religious preference, from about four million or two per cent in 1990 to more than 11 million or over five per cent in 2001. This may, however, include many religious people - for example Muslims - who wish not to disclose their affiliation. 
actually increased in contemporary 'advanced' societies. Elias sought to show that people in contemporary 'advanced' societies have to be able to maintain a fairly even and stable control over their more spontaneous libidinal, affective and emotional impulses and over their fluctuating moods. Social survival and success depend on 'a reliable armour, not too strong and not too weak, of individual self-restraint' [Elias - Dunning 2008: 24]. This applies both to occupational roles and to many private relationships and activities. In these societies, there is relatively small scope for showing strong feelings, strong dislikes of people, let alone 'hot anger, wild hatred, or the urge to hit someone over the head'.

People strongly agitated, in the grip of feelings they cannot control, are cases for hospital or prison. Conditions of high excitement are regarded as abnormal in a person, as a dangerous prelude to violence in a crowd [2008: 24]. Opportunities for a more unreflected expression of excitement are, in many spheres of social life, severely limited [2008: 51]. Yet containing strong feelings and maintaining an even control of drives throughout life are likely to lead to emotional staleness in most people (the extent varies between individuals). How is this problem to be handled socially?

In modern societies, there is an historically unparalleled variety of activities concerts, opera, plays, films, dancing, paintings, card games, novels, detective stories, thrillers, sports of all kinds, and arguably religion - that serve not simply to dissipate tensions generated in other spheres of life, but to provide opportunities for pleasurable excitement. The leisure sphere in modern societies, argue Elias and Dunning, provides an enclave within which a controlled and enjoyable decontrolling of restraints on emotions is permitted [2008: 27, 77]. These activities generally allow the emotions to flow more freely in a specially constructed setting in some ways reminiscent of non-leisure reality. Sports are an especially clear illustration of this: they always consist of a controlled struggle in an imaginary setting [2008: 33], but it is striking that some forms of religion, especially the evangelical-Pentecostalist and fundamentalist types, also involve an emotionally satisfying mimetic struggle against the forces of darkness. Sometimes, it would appear, the degree of control over the decontrolling of emotional controls is not very effective, so religious mimetic struggle spills over into the political realm. (A comparison of super-patriotic Christian fundamentalists in America with super-patriotic football hooligans in Britain might prove illuminating.)

If excitement followed by catharsis is a common need enhanced by life in modern societies, why do a larger proportion of Americans than of Europeans seek this kind of mimetic release of the emotions in religious pastimes, and apparently have done so for a long time? The constraints of the marketplace, as Haskell [1985] suggests, may have made themselves felt in the growing commercial republic at a exceptionally early stage, and the main emotional upsurges of religious feeling began before the full range of sports and cultural activities was available to most Americans. There nevertheless remains a broad question of why today Americans are more likely than Europeans to take their principal means of orientation from religious beliefs.

\section{Odd one out - Europe or the USA?}

Comparisons between the USA and Western Europe are more than usually relevant in this case, because there is a debate about whether America or Europe is the exceptional case in the world today. For decades it has been generally assumed among social scien- 
tists that secularisation was one of the characteristic part-processes of 'modernisation'. The assumption can be found in most of the classical sociologists - Marx, Durkheim, Tönnies, and most quintessentially in Max Weber's account of rationalisation and the 'disenchantment of the world'. But most of the classical sociologists were European, and drew their conclusions mainly from observing European society. They argued that 'individualism threatened the communal basis of religious belief and behaviour, while rationality removed many of the purposes of religion and rendered many of its beliefs implausible' [Bruce 1996: 230]. Why, then, should that not apply to the USA, so often characterised by its individualism?

Church membership and attendance has certainly been in steep decline in most countries of Europe for decades, even if the decline tended to set in later in Catholic regions than in Protestant. Many of those who do not attend a church may continue to have some general religious beliefs, and Grace Davie has often used the phrase 'believing without belonging' [1990, 1994]. Even so, key aspects of belief also seem noticeably lower in most European countries than in the USA. Figure 2 displays findings from the 1991 survey of religious behaviour and beliefs in the International Social Survey Programme (ISSP). In the ISSP survey, 62.8 per cent of Americans responded positively to the statement 'I know that God exists and I have no doubts about it'; although this is much lower than the 95 per cent reported from the Gallup polls as believing in God (the wording of the ISSP question, excluding every scintilla of doubt, probably set the bar higher), it is still far higher than all but a few - mainly Catholic - countries in Europe. The same is true of belief in the literal truth of the Bible, miracles and (not shown in Figure 11.2) heaven, hell, and the devil.

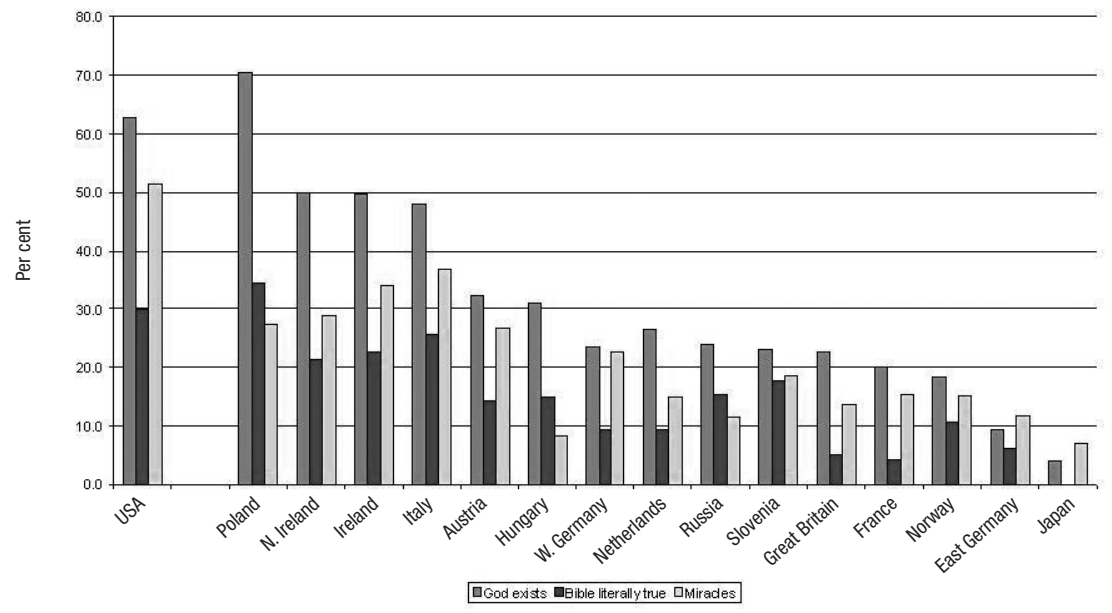

Figure 2: Religious Beliefs in USA, selected European countries and Japan.

Source: International Social Survey Programme, 1998.

Sociologists of religion have advanced diametrically opposite interpretations of these contrasts. Some have argued that religious pluralism weakens faith, because where multiple religious groups compete, each discredits the other. That was the prevalent view 
before the Stark group advanced their 'rational choice' or 'supply side' thesis. Certainly it seems to have made some difference, for example, that in France a strong anti-clerical and secularist alternative has existed since the Revolution. And more recently, large nonChristian minorities have arrived in most Western European countries. In America, the largest such minority for more than a century has been the Jews, but as already remarked a sort of Judaeo-Christian synthesis has become embodied in American 'civil religion'. The more recent growth of Islamic, Hindu, Buddhist, Sikh and other non-Christian minorities could be connected with the apparently steep increase in the non-believing minority during the 1990 s, but it is far too early for that to be more than speculation. ${ }^{17}$

In contrast, Stark and his associates contend that religious pluralism, and competition for market share between religious producers, promote religious participation and belief overall. They claim that 'religious economies can never be successfully monopolised, even when backed by the state' and that monopoly producers 'tend to be lazy' [Finke-Stark 2005: 11]. They point out that even in medieval Europe, where the Catholic Church enjoyed a monopoly, heresy was rife. (I am not sure that at the time of the Albigensian Crusade, when it deployed the most brutal means to enforce orthodoxy, the Church could be described as lazy, even if the crusade was driven by the territorial ambitions of northern French noblemen.) As for today, 'close inspection of the religious situation in societies where "everyone" is a Roman Catholic reveals levels of religious participation that are astonishingly low compared with those in America' [2005: 10].

They make an exception for the cases of Ireland and Poland, where 'the church has also served as the primary vehicle for political resistance to external domination'. But they grossly exaggerate the power of legally established churches in recent times. The Church of England, for example, has had minimal monopoly power since at least the eighteenth century, and its establishment did little to impede the expansion of Methodism, Nonconformism and Catholicism then and in the nineteenth century. Much the same could be said about the Scandinavian state churches. Religious monopolies may also form without a legal basis in establishment - the Catholic Church was never legally established in Ireland, for example, though it did for a time enjoy a verbal 'most favoured nation' status in the Republic's constitution. As Inglis [1998] has demonstrated, the Catholic Church established a hugely effective 'moral monopoly' in the Republic of Ireland. The bedrock of the moral monopoly was the Church's ownership and control of most schools and hospitals and much other social infrastructure, and the foundation for that had been laid through its alliance with the British state until shortly before the country gained independence. Weekly mass attendance persisted at extremely high rates - over 90 per cent - until near the end of the twentieth century, and heterodoxy was not a significant problem, since the church actively encouraged magical beliefs.

The argument about the effect of religious monopolies can perhaps be turned on its head. Is it possible that American Civil Religion has served as a functional equivalent to an established national church? Certainly Stark and his colleagues are right to point to the very low level of monopolisation and the vigorous competition at the micro-level of

17 An equally speculative thought is that there could be an unbelieving backlash to the political campaigns of fundamentalist pressure groups; one thinks of the T-shirt slogan 'So many right-wing Christians, so few lions'. 
specific theological doctrines and styles of worship in America. But at the more macroscopic level of fundamental beliefs in the supernatural, how much competition is there in the USA? If people are forced from childhood to swear daily allegiance to 'one nation under God', some measure of cognitive dissonance as well as courage will be involved in announcing one's belief that there is no God and no supernatural world.

\section{Conclusion}

Ultimately, whether Western Europe or America is seen as the odd one out in the process of secularisation depends on the comparators. On the face of it, it would seem obvious to compare the USA with the European countries and Japan, because those are the advanced industrial-scientific states that in other respects most resemble it. The case for America being 'normal' and Europe being exceptional rests on comparing the USA with nations of the global 'South' - or what used to be called the Third World, and before that the 'underdeveloped' world. For instance, global survey data [Pew 2003: 115-16] show that the proportion of Americans (58 per cent) in whose view it is necessary to believe in God in order to be moral - in effect a statement that moral behaviour depends upon external constraint, the fear of punishment, rather than self-constraint ${ }^{18}$ - is closer to that found in developing countries than in the rest of the industrialised world.

The debate gains a certain piquancy from many proponents of secularisation theory being non-believers, while most of their opponents among sociologists of religion appear themselves to be committed to religious belief. ${ }^{19}$ Overall, the evidence does point to a more decisive secularisation in Western Europe than anywhere else, but not so much to an 'exceptionalism' as to the widely differentiated trajectories of religious development across the globe. It appears to me, however, that some of the explanations (drawn largely from outside the normal sociology of religion) that I advance here to explain the persistence and renewal of religiosity in the USA also apply to some extent in the other continents. To these should be added the enormous prestige and power that America enjoyed in the world from the collapse of the Soviet Union until the catastrophic presidency of George W. Bush. It was a generalised reference group for masses of people across the globe, in matters ranging from its popular culture to its sublime faith in the beneficence of free markets. The apparent upsurge of religious observance and belief in formerly communist Eastern Europe probably owes a great deal to the American model making such beliefs newly respectable. On the other hand, the USA's spectacular misuse of its global power has equally fuelled the rise of Islamic movements in opposition to it; opposition movements are typically ideological bricoleurs, using the materials at hand, which in this case included a largely American invention, religious fundamentalism.

18 In German, Elias wrote of a civilising process as involving a changing balance between Fremdzwänge and Selbstzwänge.

19 See Davie [2002] for an excellent survey and bibliography of the extensive literature. Besides Europe and America, Davie includes chapters on Latin America, Africa and parts of the Far East, which I cannot discuss here. 


\section{Literature}

Ahlstrom, Sydney E. [1972]. A Religious History of the American People. New Haven: Yale University Press.

Albanese, Catherine. [1992]. America: Religions and Religion. Belmont: Wadsworth.

Armstrong, Karen. [2000]. Islam: A Short History. London: Phoenix.

Baltzell, E. Digby. [1958]. Philadelphia Gentlemen. Glencoe: Free Press.

Baltzell, E. Digby. [1979]. Puritan Boston and Quaker Phildelphia: Two Protestant Ethics and the Spirit of Class Authority and Leadership. New York: Free Press.

Bax, Mart. [1987]. Religious Regimes and State Formation: Towards a Research Perspective. Anthropological Quarterly 60 (January 1987), No. 1, s. 1-11.

Bellah, Robert N. [1967]. Civil Religion in America. Daedalus 96 (Winter 1967), No. 1, s. 1-21.

Berger, Peter. [2006]. Between relativism and fundamentalism. The American Interest 2 (September-October 2006), No. 1, s. 9-17.

Bruce, Steve. [2006]. Religion in the Modern World: from Cathedrals to Cults. Oxford: Oxford University Press.

Burkert, Walter. [1996]. Creation of the Sacred: Tracks of Biology in Early Religions. Cambridge: Harvard University Press.

Davie, Grace. [1990]. Believing without belonging: is this the future of religion in Britain? Social Compass 37 (December 1990), No. 4, s. 456-469.

Davie, Grace. [1994]. Religion in Britain since 1945: Believing without Belonging. Oxford: Blackwell.

Davie, Grace. [2002]. Europe: The Exceptional Case: Parameters of Faith in the Modern World. London: Darton, Longman \& Todd.

Eggleston, Edward. [1901]. The Transit of Civilization from England to America in the Seventeenth Century. New York: D. Appleton.

Elias, Norbert. [2000]. The Civilizing Process: Sociogenetic and Psychogenetic Investigations. Oxford: Blackwell.

Elias, Norbert. [2007a]. Involvement and Detachment. Dublin: UCD Press (Collected Works, vol. 8).

Elias, Norbert. [2007b]. An Essay on Time. Dublin: UCD Press (Collected Works, vol. 9).

Elias, Norbert. [2009]. Essays I: On the Sociology of Knowledge and the Sciences. Dublin: UCD Press (Collected Works, vol. 14).

Elias, Norbert - Dunning, Eric. [2008]. Quest for Excitement: Sport and Leisure in the Civilising Process. Dublin: UCD Press (Collected Works, vol. 7).

Elias, Norbert - Scotson, John L. [2008]. The Established and the Outsiders. Dublin: UCD Press (Collected Works, vol. 4).

Finke, Roger - Iannaccone, Laurence R. [1993]. Supply-Side Explanations for Religious Change. Annals of the American Academy of Political and Social Science 527 (May 1993), s. 27-39.

Finke, Roger - Stark, Rodney. [2005]. The Churching of America, 1776-2005: Winners and Losers in our Religious Economy. New Brunswick: Rutgers University Press.

Frazer, Sir James. [1958, (1890)]. The Golden Bough. New York: Macmillan.

Goudsblom, Johan. [1996a]. Ecological regimes and the rise of organized religion. In. Goudsblom, Johan - Jones, Eric - Mennell, Stephen. The Course of Human History: Economic Growth, Social Process, and Civilization. Armonk: M. E. Sharpe, s. 31-48.

Goudsblom, Johan. [1996b]. The Formation of Military-Agrarian Regimes. In. Goudsblom, Johan - Jones, Eric - Mennell, Stephen. The Course of Human History: Economic Growth, Social Process, and Civilization. Armonk: M. E. Sharpe, s. 49-62.

Goudsblom, Johan. [2004]. Christian Religion and the European Civilizing Process: The Views of Norbert Elias and Max Weber compared in the Context of the Augustian and Lucretian Traditions. In. Loyal, Steven - Quilley, Stephen. (eds.) The Sociology of Norbert Elias. Cambridge: Cambridge University Press.

Greeley, Andrew M. [1989]. Religious Change in America. Cambridge: Harvard University Press. 
Greeley, Andrew M. [2003]. Religion in Europe at the End of the Second Millennium: A Sociological Profile. New Brunswick: Transaction Publishers.

Harris, Marvin. [1987]. Why Nothing Works: The Anthropology of Daily Life. New York: Simon \& Schuster.

Haskell, Thomas R. [1985]. Capitalism and the Origins of Humanitarian Sensibility. American Historical Review 90 (June 1985), (No. 2-3), s. 339-361, s. 547-666.

Hedges, Chris. [2007]. American Fascists: The Christian Right and the War on America. London: Jonathan Cape.

Hunt, Morton. [1999]. The Biological Roots of Religion: Is faith in our genes? Free Inquiry 19 (Summer 1999), No. 3, s. 32-33.

Inglis, Tom. [1998]. Moral Monopoly: The Rise and Fall of the Catholic Church in Modern Ireland. Dublin: UCD Press.

Jacoby, Susan. [2005]. Caught between Church and State. The New York Times, 19 January 2005.

Jasper, James M. [2000]. Restless Nation: starting over in America. Chicago: University of Chicago Press.

Kosmin, Barry A. - Mayer, Egon - Keyser, Ariela. [2002]. American Religious Identification Survey 2001. New York: City University of New York Graduate Center.

Kristof, Nicholas D. [2003]. 'Believe it, or not'. New York Times, 15 August 2003.

Lucretius. [1951]. On the Nature of the Universe. Harmondsworth: Penguin.

Mennell, Stephen. [2007]. The American Civilizing Process. Cambridge: Polity Press.

Muchembled, Robert. [1985]. Popular Culture and Elite Culture in France, 1400-1750. Baton Rouge: Louisiana State University Press.

Pew Global Attitudes Project. [2003]. Views of a Changing World. Washington: Pew Research Centre for the People and the Press.

Putnam, Robert. [2000]. Bowling Alone: The collapse and revival of American community. New York: Simon \& Schuster.

Ribeiro, Darcy. [1971]. The Americas and Civilization. London: George Allen \& Unwin.

Stearns, Carol Z. [1988]. 'Lord help me walk humbly': Anger and sadness in England and America, 1570-1750. In. Stearns, Carol Z. - Stearns, Peter N. (eds.) Emotion and Social Change: Toward a new Psychohistory. New York: Holmes \& Meier, s. 39-69.

Swaan, Abram de. [2001]. Human Societies: An Introduction. Cambridge: Polity Press.

Thomas, Keith. [1973]. Religion and the Decline of Magic. Harmondsworth: Penguin.

Weber, Max. [1930, (1904-5)]. The Protestant Ethic and the Spirit of Capitalism. London: George Allen \& Unwin.

Weber, Max. [1946]. The Protestant Sects and the Spirit of Capitalism. In. Gerth, Hans H. - Mills, C. Wright. (eds.) From Max Weber: Essays in Sociology. New York: Oxford University Press, s. 302-322.

Wilson, Bryan. [1982]. Religion in Sociological Perspective. Oxford: Oxford University Press.

Wilson, Edward O. [1998]. Consilience. New York: Alfred A. Knopf.

Stephen Mennell is Professor Emeritus of Sociology at University College Dublin. He is a member of the Board of the Norbert Elias Foundation, Amsterdam. His books include The American Civilizing Process (2007), Norbert Elias: Civilization and the Human SelfImage (1989), Norbert Elias: An Introduction (rev. ed. 1998), and All Manners of Food (1985). 